Citation: R. Di Lecce, M. Masi, B. T. Linaldeddu, G. Pescitelli, L. Maddau, A. Evidente (2021) Bioactive secondary metabolites produced by the emerging pathogen Diplodia olivarum. Phytopathologia Mediterranea 60(1): 129-138. doi: 10.36253/phyto-12170

Accepted: January 20, 2021

Published: May 15, 2021

Copyright: @ 2021 R. Di Lecce, M. Masi, B. T. Linaldeddu, G. Pescitelli, L. Maddau, A. Evidente. This is an open access, peer-reviewed article published by Firenze University Press (http:// www.fupress.com/pm) and distributed under the terms of the Creative Commons Attribution License, which permits unrestricted use, distribution, and reproduction in any medium, provided the original author and source are credited.

Data Availability Statement: All relevant data are within the paper and its Supporting Information files.

Competing Interests: The Author(s) declare(s) no conflict of interest.

Editor: Luisa Ghelardini, University of Florence, Italy.

\section{Research Papers \\ Bioactive secondary metabolites produced by the emerging pathogen Diplodia olivarum}

\author{
Roberta DI LECCE ${ }^{1}$, Marco MASI $^{1, *}$, BenedetTo Teodoro LINALDEDDU $^{2}$, \\ GenNARo PESCITELLI ${ }^{3}$, LuCia MADDAU 4 , Antonio EVIDENTE ${ }^{1}$ \\ ${ }^{1}$ Dipartimento di Scienze Chimiche, Università di Napoli Federico II, Complesso Univer- \\ sitario Monte Sant'Angelo, Via Cintia 4, 80126, Napoli, Italy \\ 2 Dipartimento Territorio e Sistemi Agro-Forestali, Università di Padova, Viale \\ dell'Università 16, Legnaro 35020, Italy \\ ${ }^{3}$ Dipartimento di Chimica e Chimica Industriale, Università di Pisa, Via Moruzzi 13, \\ 56124 Pisa, Italy \\ ${ }^{4}$ Dipartimento di Agraria, Sezione di Patologia Vegetale ed Entomologia, Università degli \\ Studi di Sassari, Viale Italia 39, 07100, Sassari, Italy \\ *Corresponding author. E-mail: marco.masi@unina.it
}

Summary. A new cleistanthane nor-diterpenoid, named olicleistanone (1), was isolated as a racemate from the culture filtrates of Diplodia olivarum, an emerging pathogen involved in the aetiology of branch canker and dieback of several plant species typical of the Mediterranean maquis in Sardinia, Italy. When the fungus was grown in vitro on Czapek medium, olicleistanone was isolated together with some already known phytotoxic diterpenoids identified as sphaeropsidins A, C, and G, and diplopimarane (2-5). Olicleistanone was characterized as 4-ethoxy-6a-methoxy-3,8,8-trimethyl-4,5,8,9,10,11hexahydrodibenzo[de,g]chromen-7(6aH)-one. When D. olivarum was grown on mineral salt medium it produced (-)-mellein (6), sphaeropsidin A and small amounts of sphaeropsidin $\mathrm{G}$ and diplopimarane. Olicleistanone (1) exhibited strong activity against the insect Artemia salina L. (100\% larval mortality) at $100 \mu \mathrm{g} \mathrm{mL} \mathrm{m}^{-1}$ but did not exhibit phytotoxic, antifungal or antioomycete activity. Among the metabolites isolated (1-6), sphaeropsidin A (2) was active in all bioassays performed exhibiting strong phytotoxicity on leaves of Phaseolus vulgaris L., Juglans regia L. and Quercus suber L. at $1 \mathrm{mg}$ $\mathrm{mL}^{-1}$. Sphaeropsidin A (2) also completely inhibited mycelium growth of Athelia rolfsii, Diplodia corticola, Phytophthora cambivora and P. lacustris at $200 \mu \mathrm{g}$ per plug, and was active in the Artemia salina assay. Also in this assay, diplopimarane (5) and sphaeropsidin G (4) were active (100\% larval mortality). Diplopimarane also showed antifungal and antioomycete activities. Athelia rolfsii was the most sensitive species to diplopimarane. Sphaeropsidin C (3) and (-)-mellein (6) were inactive in all bioassays. These results expand knowledge on the metabolic profile of Botryosphaeriaceae, and embody the first characterization of the main secondary metabolites secreted by D. olivarum.

Keywords. Botryosphaeriaceae, forest ecosystems, olicleistanone, toxins.

\section{INTRODUCTION}

Diplodia Fr. is a large genus in the Botryosphaeriaceae, typified by Diplodia mutila (Fr.: Fr.) Fr. (Alves et al., 2014). Species of Diplodia are cosmopoli- 
tan in temperate and subtropical regions, and occur on a wide range of angiosperm and gymnosperm hosts (Masi et al., 2018). They exhibit diverse lifestyles, from endophytes inhabiting asymptomatic plant tissues to aggressive pathogens that cause severe diseases in various plant hosts (Pérez et al., 2010; Adamson et al., 2015; Martin et al., 2017; Masi et al., 2018). The increasing number of reports of new diseases caused by these pathogens has stimulated research into the virulence factors involved in their pathogenesis processes. Several bioactive secondary metabolites were isolated and characterized from the emerging Diplodia pathogenic species D. africana, D. corticola, D. cupressi, D. fraxini, D. quercivora and $D$. sapinea. These metabolites belong to different classes of organic compounds including pimarane diterpenoids, a-pyrones, furanones, diplobifuranylones, naphthoquinones, biphenols, cyclohexene oxides, furopyrans, isochromanones and melleins (Evidente et al., 2012; Andolfi et al., 2014; Cimmino et al., 2016; Cimmino et al., 2017a; Masi et al., 2018). Some phytotoxins produced by Diplodia species (e.g. the tetracyclic pimarane diterpenoid, sphaeropsidin A) have broad-spectra of biological properties, including anticancer activity (Masi et al., 2018).

Recently, Diplodia olivarum has emerged as an aggressive pathogen on different plant hosts in Italy. This fungus was first found on rotting olive drupes in southern Italy, and was described as a new species in 2008 (Lazzizera et al., 2008). It was later reported as a cause of canker on carob tree (Granata et al., 2011), lentisk (Linaldeddu et al., 2016) and wild olive (Manca et al., 2020). Symptoms caused by the pathogen in infected hosts include sunken cankers with characteristic wedgeshaped wood necroses on branches and stems. Foliar symptoms have also been observed especially on lentisk shoots (Figure 1).

Given the expansion of severe dieback caused by $D$. olivarum in several natural ecosystems in Italy, and the limited information available about bioactive secondary metabolites produced by this emerging pathogen, the study described here was conducted to isolate, identify and evaluate phytotoxic, antifungal, antioomycetes and zootoxic activities of the main compounds produced by D. olivarum

\section{MATERIALS AND METHODS}

\section{Chemical characterization procedures}

Optical rotations were measured in $\mathrm{MeOH}$ on a P-1010 digital polarimeter (Jasco, Tokyo, Japan), unless otherwise noted. IR spectra were recorded as a glass film deposits using a 5700 FT-IR spectrometer (Jasco), and

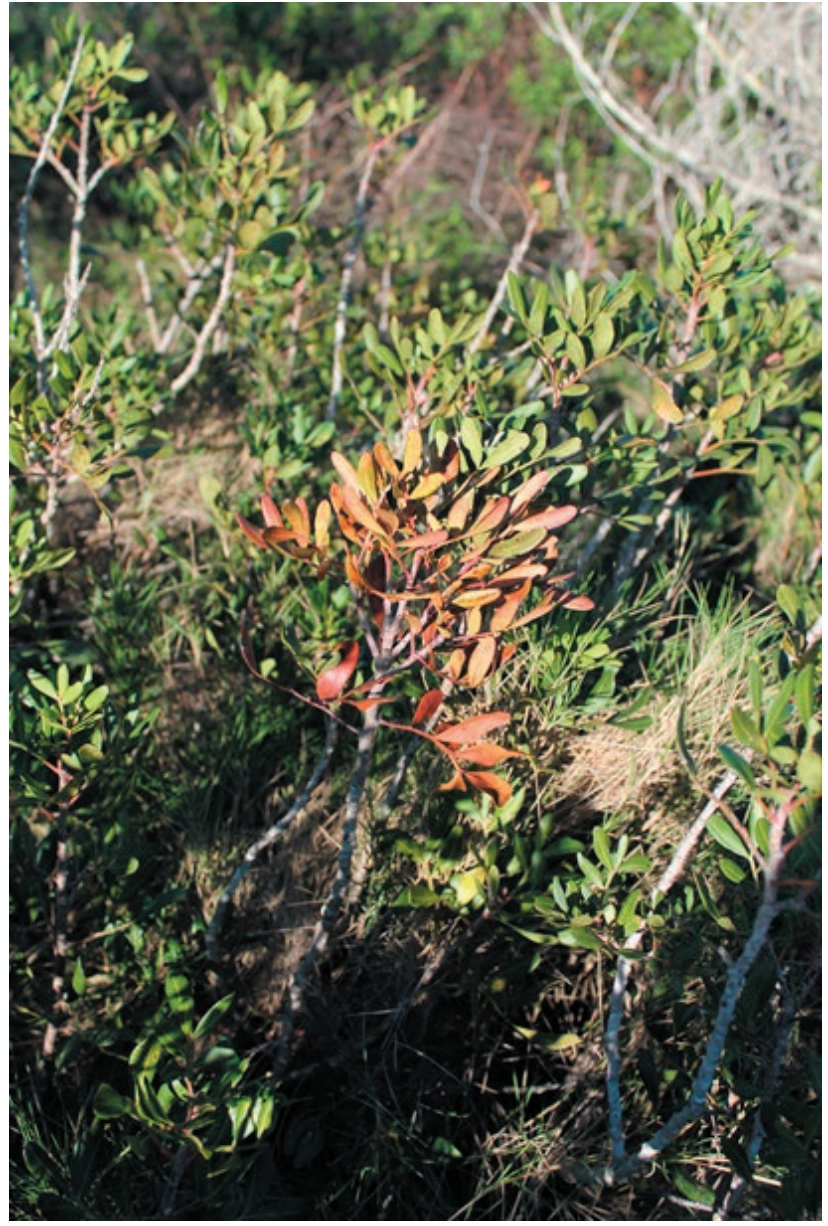

Figure 1. Foliar symptoms on lentisk shoots infected by Diplodia olivarum.

UV spectra were measured in $\mathrm{MeCN}$ on a V-530 spectrophotometer (Easton). ${ }^{1} \mathrm{H}$ and ${ }^{13} \mathrm{C}$ NMR spectra were recorded, respectively, at 400 and $100 \mathrm{MHz}$ in $\mathrm{CDCl}_{3}$, on a Bruker spectrometer (Billerica), using the same solvent as internal standard. The multiplicities were determined by DEPT spectrum (Berger and Braun, 2004). COSY, HSQC, HMBC and NOESY spectra were recorded using Bruker microprograms. HR ESIMS spectra were recorded on a 6120 Quadrupole LC/MS instrument (Agilent Technologies). Analytical (0.25 mm thickness) and preparative TLC $(0.50 \mathrm{~mm}$ thickness) were performed on silica gel (Kieselgel $60, \mathrm{~F}_{254}$ ) and on reversed phase (Kieselgel $60 \mathrm{RP}-18, \mathrm{~F}_{254}, 0.20 \mathrm{~mm}$ tickness) plates (Merck). Resulting spots were visualized by exposure to UV radiation $(253 \mathrm{~nm})$, or by spraying first with $10 \% \mathrm{H}_{2} \mathrm{SO}_{4}$ in $\mathrm{MeOH}$ and then with $5 \%$ phosphomolybdic acid in $\mathrm{EtOH}$, followed by heating at $110^{\circ} \mathrm{C}$ for $10 \mathrm{~min}$. Column chromatography was performed using silica gel (Merck, Kieselgel 60, 0.063-0.200 mm). 


\section{Fungus strain}

The D. olivarum strain used in this study was originally isolated from a cankered branch of lentisk collected in a natural area on Caprera Island (Italy). Representative genetic sequences from this strain were deposited in GenBank, with the accession numbers: ITS; KX833078), tef1- $\alpha$; KX833079) and MAT1-2-1; MG015783 (Lopes et al., 2018). Pure cultures were maintained on potato dextrose agar (PDA) (Fluka, SigmaAldrich Chemic $\mathrm{GmbH}$ ) and were stored at $4^{\circ} \mathrm{C}$ in the collection of the Dipartimento di Agraria, University of Sassari, Italy, as BL96.

Production, extraction and purification of secondary metabolites

Diplodia olivarum was grown on Czapek broth amended with $2 \%$ yeast extract or mineral salt medium (Pinkerton and Strobel, 1976), both at $\mathrm{pH} 5.7$ in $1 \mathrm{~L}$ capacity Erlenmeyer flasks each containing $250 \mathrm{~mL}$ of medium. Each flask was seeded with $5 \mathrm{~mL}$ of a mycelium suspension and then incubated for $30 \mathrm{~d}$ at $25^{\circ} \mathrm{C}$. Culture filtrates were obtained by filtering the cultures through filter paper in a vacuum system.

The filtrate $(14.5 \mathrm{~L})$, obtained growing the fungus on Czapek medium, was acidified to $\mathrm{pH} 4$ with $2 \mathrm{~N} \mathrm{HCl}$ and extracted exhaustively with EtOAc. The combined organic extracts were dried with $\mathrm{Na}_{2} \mathrm{SO}_{4}$ and evaporated under reduced pressure. The brown-red oil residue recovered $(4.5 \mathrm{~g})$ was fractioned by column chromatography on silica gel $(90 \times 4 \mathrm{~cm})$ eluted with $n$-hexaneEtOAc (7:3). Eleven fractions were collected and pooled on the basis of similar TLC profiles. Fraction 2 (195.2 $\mathrm{mg}$ ) was purified by column chromatography on silica gel, eluted with petroleum ether-EtOAc (9.5:0.5), and yielded 13 homogeneous fractions. The residue of the fourth fraction from this latter column $(11.0 \mathrm{mg})$ was further purified by TLC, eluted with $n$-hexane-acetone (8.5:1.5), and yielded sphaeropsidin G, 4 [6.7 mg, 0.46 $\mathrm{mg} \mathrm{L}{ }^{-1}, \mathrm{R}_{f} 0.82$, eluent $n$-hexane-acetone (8.5:1.5)] as an amorphous solid. The residue of the third fraction (103.2 $\mathrm{mg}$ ) was purified by column chromatography on silica gel $(75 \times 3 \mathrm{~cm})$, eluted with $\mathrm{CHCl}_{3}$-isoPrOH (93:7), and yielded eight homogeneous fractions. The residue of the third fraction from this latter column $(23.0 \mathrm{mg})$ was crystallized with EtOAc- $n$-hexane (1:5) to give diplopimarane, 5 [14.2 mg, $0.97 \mathrm{mg} \mathrm{L}^{-1}, \mathrm{R}_{f} 0.7$, eluent $n$-hexaneEtOAc (7:3)] as white crystals. The residue of the eighth fraction $(56.4 \mathrm{mg})$ was purified by preparative TLC, eluted with $n$-hexane- $\mathrm{CHCl}_{3}$-isoPrOH (8:1.5:0.5), and yielded olicleistanone (1) as an amorphous solid [5.8 mg, $0.4 \mathrm{mg} \mathrm{L}^{-1}, \mathrm{R}_{f} 0.45$, eluent $n$-hexane- $\mathrm{CHCl}_{3}$-isoPrOH (8:1.5:0.5)]. The residues from the fifth $(290.3 \mathrm{mg})$ and sixth $(278.9 \mathrm{mg})$ fractions from the first column were combined and crystallized with EtOAc- $n$-hexane (1:5) to give sphaeropsidin A, 2 [312.6 mg, $\mathrm{R}_{f} 0.5$, eluent $n$-hexane-acetone (7:3), $\mathrm{R}_{f} 0.7$, eluent $n$-hexane-EtOAc (6:4)] as white crystals. The residue of the seventh fraction (135.1 $\mathrm{mg}$ ) from the first column was purified by $\mathrm{CC}$ on silica gel, eluent $n$-hexane-EtOAc-acetone (6:2.5:1.5), giving sphaeropsidin C, 3 [53.3 mg, $3.67 \mathrm{mg} \mathrm{L}^{-1}, \mathrm{R}_{f} 0.52$, eluent $n$-hexane-EtOAc-acetone (6:2.5:1.5), $\mathrm{R}_{f} 0.63$, eluent $n$-hexane-EtOAc (6:4)] as a white solid, and a further amount of sphaeropsidin A, 2 (33.2 mg, total yield 23.7 $\left.\mathrm{mg} \mathrm{L}^{-1}\right)$.

The culture filtrate $(10.0 \mathrm{~L})$ obtained growing the fungus on modified mineral medium was extracted following the procedure described above to obtain $3.2 \mathrm{~g}$ of organic extract. This was fractioned by column chromatography on silica gel $(80 \times 4 \mathrm{~cm})$ eluted with $n$-hexane-EtOAc (7:3), and yielded ten groups of homogeneous fractions. The residue of the third fraction ( 302.3 $\mathrm{mg}$ ) was purified by column chromatography on silica gel $(75 \times 3 \mathrm{~cm})$, eluted with $n$-hexane- $\mathrm{CHCl}_{3}$-isoPrOH (7.5:2:0.5), and yielded diplopimarane $(5 ; 1.4 \mathrm{mg}, 0.01$ $\left.\mathrm{mg} \mathrm{L}^{-1}\right)$ and (-)-mellein [6; $105.8 \mathrm{mg}, 7.30 \mathrm{mg} \mathrm{L}^{-1}, \mathrm{R}_{f} 0.65$, eluent $n$-hexane- $\mathrm{CHCl}_{3}$-isoPrOH (7.5:2:0.5)]. The residue of the fourth fraction of the first column $(8.2 \mathrm{mg})$ was further purified by TLC, eluted with $n$-hexane-acetone (8.5:1.5), and yielded sphaeropsidin G $(4 ; 1.5 \mathrm{mg}, 0.10$ $\left.\mathrm{mg} \mathrm{L}^{-1}\right)$. The residue of the fifth $(815.9 \mathrm{mg})$ fraction of the first column was crystallized with EtOAc- $n$-hexane (1:5) to give sphaeropsidin A $\left(2 ; 677 \mathrm{mg}, 46.69 \mathrm{mg} / \mathrm{L}^{-1}\right)$.

\section{Spectroscopic data of secondary metabolites}

Olicleistanone (1): UV $\lambda_{\max }(\log \varepsilon) 333$ (2.98), 241 (3.55) $\mathrm{nm}$; IR $v_{\max } 1725,1610,1592,1560,1458 \mathrm{~cm}^{-1} ;{ }^{1} \mathrm{H}$ and ${ }^{13} \mathrm{C}$ NMR: Table 1; HRESI -MS (+) spectrum $m / z: 735$ $[2 \mathrm{M}+\mathrm{Na}]^{+}, 395[\mathrm{M}+\mathrm{K}]^{+}, 379.1876\left[\mathrm{C}_{22} \mathrm{H}_{28} \mathrm{Na} \mathrm{O}_{4}\right.$, calcd. $379.1885, \mathrm{M}+\mathrm{Na}]^{+}, 311\left[\mathrm{M}+\mathrm{H}-\mathrm{CH}_{3} \mathrm{CH}_{2} \mathrm{OH}\right]^{+}$.

Sphaeropsidin A (2): $[\alpha]_{\mathrm{D}}^{25}+104($ c 0.4, $\mathrm{MeOH})$; [lit. (Evidente et al., 1996): $[\alpha]_{D}{ }^{25}+109.6$ (c 0.2, MeOH); ${ }^{1} \mathrm{H}$ NMR is very similar to that previously reported (Evidente et al., 1996); HRESI-MS (+) spectrum $m / z: 715[2 \mathrm{M}+\mathrm{Na}]^{+}$, $369[\mathrm{M}+\mathrm{Na}]^{+}, 347.1820\left[\mathrm{C}_{20} \mathrm{H}_{27} \mathrm{O}_{5}\right.$, calcd. 347.1780, $\mathrm{M}+\mathrm{H}]^{+}$.

Sphaeropsidin C (3): $[\alpha]_{\mathrm{D}}^{25}+18.3(c$ 0.7, $\mathrm{MeOH})$; [lit. (Evidente et al., 1997): $[\alpha]_{\mathrm{D}}^{25}+16.8$ (c 1.0, MeOH)]; ${ }^{1} \mathrm{H}$ NMR is very similar to that previously reported (Evidente et al., 1997); HRESI-MS (+) spectrum $m / z$ : 
$703[2 \mathrm{M}+\mathrm{K}]^{+}, 687[2 \mathrm{M}+\mathrm{Na}]^{+}, 665[2 \mathrm{M}+\mathrm{H}]^{+}, 333.2037$ $\left[\mathrm{C}_{20} \mathrm{H}_{29} \mathrm{O}_{4} \text {, calcd. 333.2066, } \mathrm{M}+\mathrm{H}\right]^{+}$.

Sphaeropsidin G (4): $[\alpha]_{\mathrm{D}}{ }^{25}+48.6\left(c\right.$ 0.8, $\left.\mathrm{CHCl}_{3}\right)$ [lit. (Cimmino et al., 2016): $[\alpha]_{\mathrm{D}}{ }^{25}+51.4\left(c\right.$ 0.56, $\left.\left.\mathrm{CHCl}_{3}\right)\right] ;{ }^{1} \mathrm{H}$ NMR is very similar to that previously reported (Cimmino et al., 2016); ESI-MS (+) spectrum $\mathrm{m} / z: 309[\mathrm{M}+$ $\mathrm{K}]^{+}, 293[\mathrm{M}+\mathrm{Na}]^{+}, 271[\mathrm{M}+\mathrm{H}]^{+}$.

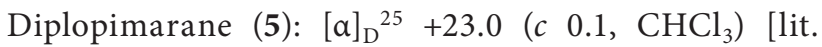
(Andolfi et al., 2014): $\left.[\alpha]_{\mathrm{D}}{ }^{25}+25.8\left(c \quad 0.6, \mathrm{CHCl}_{3}\right)\right] ;{ }^{1} \mathrm{H}$ NMR is very similar to that previously reported (Andolfi et al., 2014); ESIMS (+) spectrum $m / z: 623[2 \mathrm{M}-4 \mathrm{H}+$ $\mathrm{Na}]^{+}, 339[\mathrm{M}-2 \mathrm{H}+\mathrm{K}]^{+}, 325[\mathrm{M}+\mathrm{Na}]^{+}, 323[\mathrm{M}-2 \mathrm{H}+$ $\mathrm{Na}]^{+}$.

(-)-Mellein (6): $[\alpha]^{25} \mathrm{D}-93.0($ c $0.3 \mathrm{MeOH})$ [lit. (Masi et al., 2020): $\left.[\alpha]^{25}{ }_{\mathrm{D}}-90\left(c \mathrm{c} 0.2, \mathrm{CH}_{3} \mathrm{OH}\right)\right] ;{ }^{1} \mathrm{H}$ NMR is similar to that previously reported (Masi et al., 2020); ESI MS (+) spectrum $m / z: 179[\mathrm{M}+\mathrm{H}]^{+}$.

\section{Computational methods}

Molecular mechanics, Hartree-Fock (HF) and density functional theory (DFT) calculations were run with Spartan'18 (Wavefunction, Inc. 2018), with standard parameters and convergence criteria.

First, the conformers of $(7 S, 15 S)-\mathbf{1}$ and $(7 S, 15 R)-\mathbf{1}$ were investigated with the Monte Carlo algorithm using Merck molecular force field (MMFF). They were then screened by geometry optimizations at HF/3-21G level, single-point calculations at B3LYP/6-31G(d) level, and final geometry optimizations at the same level. Energies and populations were then estimated at the B97M-V/6-311+G(2df,2p) level. The procedure gave six energy minima for $(7 S, 15 S)-\mathbf{1}$ and ten minima for $(7 S, 15 R)$-1 within the final energy threshold $\left(10 \mathrm{~kJ} \mathrm{~mol}^{-1}\right.$ at the B97M-V/6-31G(d) level). ${ }^{13} \mathrm{C}-\mathrm{NMR}$ chemical shifts were then calculated with the GIAO method at the B3LYP/6-31G(d) level. An empirical correction was applied to each molecule depending on the number of bonds to the carbon and on the bond lengths (Hehre et al., 2019). ${ }^{3} \mathrm{~J}$ coupling constants were determined as Boltzmann averages of all the DFT structures described above, either with Karplus equations or at B3LYP/pcJ-0 levels (Fermi contact term only).

\section{Leaf puncture assays}

Leaves of Phaseolus vulgaris L, Juglans regia L. and Quercus suber L. were used for this assay, and each compound was tested at $1.0 \mathrm{mg} \mathrm{mL}^{-1}$. The assays were per- formed as previously reported (Andolfi et al., 2014), and each treatment was repeated three times. Leaves were observed daily and scored for symptoms after $5 \mathrm{~d}$. The effects of the toxins on the leaves were observed up to 10 $\mathrm{d}$. Lesions were estimated using APS Assess 2.0 software following the tutorials in the user's manual. Lesion size was expressed in $\mathrm{mm}^{2}$.

\section{Antifungal assays}

All compounds (1-6) were preliminarily tested on four different plant pathogens including the two fungi (Athelia rolfsii and D. corticola) and the two oomycetes (Phytophthora cambivora and P. lacustris). The sensitivity of all four species to these compounds was evaluated, depending on the species, on carrot agar (CA) or potato dextrose agar (PDA), as inhibition of the mycelium radial growth. The assays were performed as previously reported (Masi et al., 2016). Each metabolite was tested at $200 \mu \mathrm{g}$ per plug. Methanol was used as negative controls. Metalaxyl-M (mefenoxam; p.a. 43.88\%; Syngenta), a synthetic fungicide to which the oomycetes are sensitive, and PCNB (pentachloronitrobenzene) for ascomycetes and basidiomycetes, were used as positive controls. Each treatment consisted of three replicates, and the experiment was repeated two times

\section{Artemia salina bioassays}

All compounds were assayed on brine shrimp larvae (Artemia salina L.). The assay was performed in cell culture plates with 24 cells (Corning) as previously described (Andolfi et al., 2014). The metabolites were tested at $100 \mathrm{mg} \mathrm{mL}^{-1}$. Tests were performed in quadruplicate. The proportions (\%) of larval mortality was determined after $36 \mathrm{~h}$ incubation at $27^{\circ} \mathrm{C}$ in the dark.

\section{RESULTS AND DISCUSSION}

The organic extract obtained from filtrates of D. olivarum culture grown on Czapek medium was purified to yield a new nor-diterpenoid cleistanthane (1; Figure 2), named here as olicleistanone, together with two known pimarane diterpenoids identified as sphaeropsidins $\mathrm{A}$ and $\mathrm{C}$ (respectively 2 and 3; Figure 2), and two known norpimarane diterpenoids identified as sphaeropsidin $G$ and diplopimarane (respectively, 4 and 5; Figure 2). When the fungus was grown on mineral salt medium it produced (-)-mellein (6; Figure 2), sphaeropsidin A (2) and low amounts of sphaeropsidin G (4) and diplopimarane (5). 


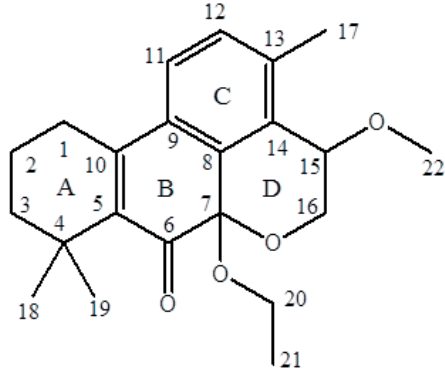

1, Olicleistanone

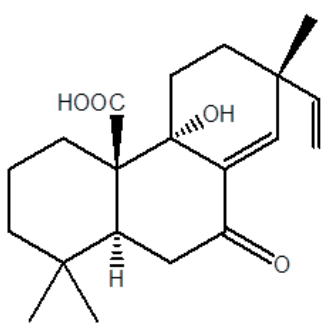

3, Sphaeropsidin C

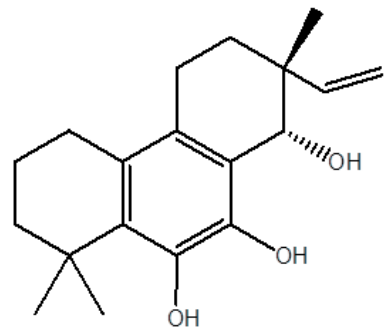

5. Diplopimarane

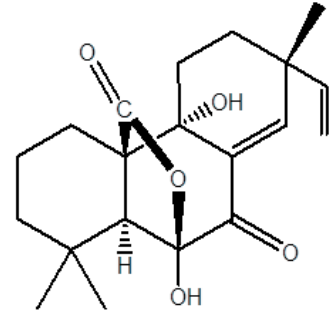

2, Sphaeropsidin A

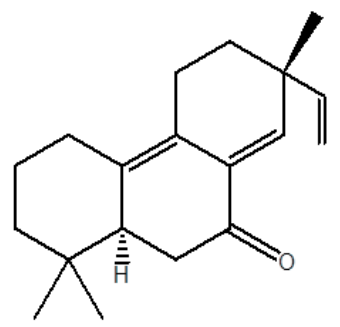

4, Sphaeropsidin G

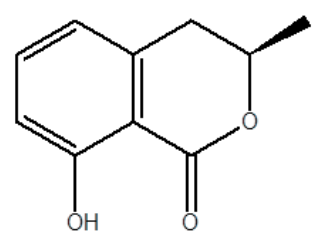

$6(-)$-Mellein
Figure 2. Structures of olicleistanone (1), sphaeropsidins A, C and $\mathrm{G}(2,3$ and 4), diplopimarane (5) and (-)-mellein (6).

The known compounds (2 to 6 ) were identified comparing their physical (specific optical rotation) and spectroscopic data ( ${ }^{1} \mathrm{H}$ NMR and ESIMS) with those previously reported (Evidente et al., 1996; Evidente et al., 1997; Evidente et al., 2010; Andolfi et al., 2014; Abou-Mansour et al., 2015; Cimmino et al., 2016; Cimmino et al. 2017b; Masi et al., 2018; Masi et al., 2020).

Olicleistanone (1) has a molecular formula of $\mathrm{C}_{22} \mathrm{H}_{28} \mathrm{O}_{4}$, as deduced from its HR ESIMS spectrum and consistent with nine hydrogen deficiencies. Preliminary investigation of its ${ }^{1} \mathrm{H}$ and ${ }^{13} \mathrm{C}$ NMR spectra (Table 1 ) showed that the compound is closely related to a tricyclic nor-diterpenoid, with aromatized and cyclohexadiene rings $(\mathrm{C}$ and $\mathrm{B})$ joined to a dihydropyran ring $(\mathrm{D})$ generated probably from a cleistanthane carbon skeleton (Devappa et al., 2011). The signal at $\delta 195.5$ in the ${ }^{13} \mathrm{C}$ NMR spectrum also showed the presence of a conjugated ketone group (Breitmaier and Voelter, 1987). These results are in full agreement with the bands typical for carbonyl and aromatic groups observed in the IR spectrum (Najkanishi and Solomns 1977) and the absorption maxima observed in the UV spectrum (Pretsch et al., 2000).

The ${ }^{1} \mathrm{H}$ and COSY spectra (Berger and Braun, 2004) of olicleistanone (1) showed the presence of the typical signals of two ortho-coupled protons ( $\mathrm{H}-11$ and $\mathrm{H}-12)$ of a 1,2,3,4-tetrasubstituted $\mathrm{C}$ benzene ring, and the singlets of a methoxy group $\left(\mathrm{CH}_{3}-22\right)$, a vinyl methyl $\left(\mathrm{CH}_{3}-\right.$ 17) and two methyls $\left(\mathrm{CH}_{3}-19\right.$ and $\left.\mathrm{CH}_{3}-18\right)$ bonded to a quaternary carbon. The two methyls represent the head of the geranylgeranyl biosynthetic precursor which generated the diterpenoid cleistanthane carbon skeleton. The same spectra showed the signal of an ethoxy group. A signal pattern due to pyran moiety (ring D) of the benzohydropyran system ( $\mathrm{C}$ and $\mathrm{D}$ rings) appeared as an $\mathrm{ABC}$ system. The spectra also showed a signal typical of the three adjacent methylene groups $\left(\mathrm{CH}_{2}-1, \mathrm{CH}_{2}-2\right.$ and $\mathrm{CH}_{2}-3$ ) of the A ring (Pretsch et al., 2000).

The correlations observed in the HSQC spectrum (Berger and Braun, 2004) allowed the chemical shifts to be assigned to the protonated carbons, as reported in Table 1 (Breitmaier and Voelter, 1987).

The long range couplings observed in the $\mathrm{HMBC}$ spectrum (Berger and Braun, 2004) (Table 1) allowed the quaternary carbons to be assigned. The signals at $\delta$ 34.0 correlated with $\mathrm{H}_{2}-2, \mathrm{H}_{2}-3, \mathrm{H}_{3}-18$ and $\mathrm{H}_{3}-19$ and were assigned to $\mathrm{C}-4$, at 136.4 with $\mathrm{H}_{2}-1, \mathrm{H}_{2}-3, \mathrm{H}_{3}-18$ and $\mathrm{H}_{3}-19$ and assigned to $\mathrm{C}-5$, at 195.5 with $\mathrm{H}_{2}-1$ and assigned to $\mathrm{C}-6$, at 92.3 with $\mathrm{H}-15, \mathrm{H}_{2}-16$ and $\mathrm{H}-20 \mathrm{~A}$ and assigned to C-7, at 130.6 with $\mathrm{H}-12$ and $\mathrm{H}_{3}-17$ and assigned to $\mathrm{C}-8$, at 146.1 with $\mathrm{H}_{2}-1, \mathrm{H}_{2}-2, \mathrm{H}-11$ and assigned to $\mathrm{C}-10$, at 138.7 with $\mathrm{H}-11$ and $\mathrm{H}_{3}-17$ and assigned to $\mathrm{C}-13$, and at 130.2 with $\mathrm{H}-12, \mathrm{H}-15$ and $\mathrm{H}_{2}-16$ and assigned to $\mathrm{C}-14$. The remaining signal at $\delta 132.9$ was assigned to C-9 (Breitmaier and Voelter, 1987). The correlation between C-7 and H-20A allowed the ethoxy group to be located at C-7 and consequently the methoxy group at C-15. Ethoxy groups are relatively rare in natural products, but not unprecedented, including several ethoxy-containing ketals like $\mathbf{1}$ (Wang et al., 2006; Lim et al., 2013; Xiong et al., 2015; Shen et al., 2015; Zhang et al., 2016). We avoided the use of ethanol during the extraction or purification process, which could lead to $\mathbf{1}$ as an artifact (Maltese et al., 2009; Capon, 2020).

Thus, the chemical shifts were assigned to all the carbons and the corresponding protons, which are reported in Table 1, and olicleistanone (1) was formulated as 4 -ethoxy-6a-methoxy-3,8,8-trimethyl-4,5,8,9,10,11hexahydrodibenzo[de,g]chromen-7(6aH)-one. 
Table 1. ${ }^{1} \mathrm{H}$ and ${ }^{13} \mathrm{C}$ NMR and $\mathrm{HMBC}$ data for olicleistanone $(\mathbf{1})^{a, b}$.

\begin{tabular}{|c|c|c|c|}
\hline Position & $\delta_{C}^{c}$ & $\delta_{\mathrm{H}}(J$ in $\mathrm{Hz})$ & HMBC \\
\hline \multicolumn{4}{|c|}{$2.77(1 \mathrm{H}) \mathrm{dt}(18.8,6.1)$} \\
\hline 1 & $27.4 \mathrm{t}$ & $\begin{array}{c}2.47(1 \mathrm{H}) \text { ddd }(18.8, \\
12.2,6.6)\end{array}$ & $\mathrm{H}_{2}-2, \mathrm{H}_{2}-3$ \\
\hline 2 & $18.6 \mathrm{t}$ & $1.80 \mathrm{~m}(2 \mathrm{H})$ & $\mathrm{H}_{2}-1$ \\
\hline 3 & $40.5 \mathrm{t}$ & $\begin{array}{l}1.62(1 \mathrm{H}) \mathrm{m} \\
1.49(1 \mathrm{H}) \mathrm{m}\end{array}$ & $\mathrm{H}_{2}-1, \mathrm{H}_{2}-2, \mathrm{H}_{3}-18, \mathrm{H}_{3}-19$ \\
\hline 4 & $34.0 \mathrm{~s}$ & & $\mathrm{H}_{2}-2, \mathrm{H}_{2}-3, \mathrm{H}_{3}-18, \mathrm{H}_{3}-19$ \\
\hline 5 & $136.4 \mathrm{~s}$ & & $\mathrm{H}_{2}-1, \mathrm{H}_{2}-3, \mathrm{H}_{3}-18, \mathrm{H}_{3}-19$ \\
\hline 6 & $195.5 \mathrm{~s}$ & & $\mathrm{H}_{2}-1$ \\
\hline 7 & $92.3 \mathrm{~s}$ & & $\mathrm{H}-15, \mathrm{H}_{2}-16, \mathrm{H}-20 \mathrm{~A}$ \\
\hline 8 & $130.6 \mathrm{~s}$ & & $\mathrm{H}-12, \mathrm{H}_{3}-17$ \\
\hline 9 & $132.9 \mathrm{~s}$ & & \\
\hline 10 & $146.1 \mathrm{~s}$ & & $\mathrm{H}_{2}-1, \mathrm{H}_{2}-2, \mathrm{H}-11$ \\
\hline 11 & $125.0 \mathrm{~d}$ & $7.31(1 \mathrm{H}) \mathrm{d}(7.9)$ & \\
\hline 12 & $131.3 \mathrm{~d}$ & $7.18(1 \mathrm{H}) \mathrm{d}(7.9)$ & \\
\hline 13 & $138.7 \mathrm{~s}$ & & $\mathrm{H}-11, \mathrm{H}_{3}-17$ \\
\hline 14 & $130.2 \mathrm{~s}$ & & $\mathrm{H}-12, \mathrm{H}-15, \mathrm{H}_{2}-16$ \\
\hline 15 & $69.5 \mathrm{~d}$ & $4.20(1 \mathrm{H}) \mathrm{d}(3.3)^{\mathrm{e}}$ & $\mathrm{H}_{2}-16, \mathrm{H}_{3}-22$ \\
\hline 16 & $60.5 \mathrm{t}$ & $\begin{array}{c}.22(1 \mathrm{H}) \mathrm{dd}(12.7,3.3)^{\mathrm{e}} \\
4.41(1 \mathrm{H}) \mathrm{d}(12.7)\end{array}$ & H-15 \\
\hline 17 & $18.4 \mathrm{q}$ & $2.34(3 \mathrm{H}) \mathrm{s}$ & $\mathrm{H}-12$ \\
\hline $18^{\mathrm{d}}$ & $27.7 \mathrm{q}$ & $1.23(3 \mathrm{H}) \mathrm{s}$ & $\mathrm{H}_{3}-19$ \\
\hline $19^{\mathrm{d}}$ & $29.7 \mathrm{q}$ & $1.36(3 \mathrm{H}) \mathrm{s}$ & $\mathrm{H}_{3}-18$ \\
\hline 20 & $59.0 \mathrm{t}$ & $\begin{array}{l}3.33(1 \mathrm{H}) \mathrm{dq}(14.2,7.0) \\
3.64(1 \mathrm{H}) \mathrm{dq}(14.2,7.0)\end{array}$ & $\mathrm{H}_{3}-21$ \\
\hline 21 & $15.4 \mathrm{q}$ & $1.14(3 \mathrm{H}) \mathrm{t}(7.0)$ & \\
\hline 22 & $55.7 \mathrm{q}$ & $3.38(3 \mathrm{H}) \mathrm{s}$ & H-15 \\
\hline
\end{tabular}

a $2 \mathrm{D}{ }^{1} \mathrm{H},{ }^{1} \mathrm{H}(\mathrm{COSY})$ and ${ }^{13} \mathrm{C},{ }^{1} \mathrm{H}$ (HSQC) NMR experiments confirmed the correlations of all the protons and the corresponding carbons.

${ }^{\mathrm{b}}$ Coupling constants $(J)$ are given in parenthesis.

${ }^{c}$ Multiplicities were assigned with DEPT.

d These signals could be exchanged.

${ }^{\mathrm{e}}$ These two signals are in part overlapped.

The structure assigned to 1 was supported by the other HMBC couplings reported in Table 1 and from the data of its HR ESIMS spectrum which showed the sodium dimer $[2 \mathrm{M}+\mathrm{Na}]^{+}$, the potassium $[\mathrm{M}+\mathrm{K}]^{+}$and the sodium $[\mathrm{M}+\mathrm{Na}]^{+}$adducts at $m / z: 735,395,379.1876$. The significant ion $\left[\mathrm{M}+\mathrm{H}-\mathrm{CH}_{3} \mathrm{CH}_{2} \mathrm{OH}\right]^{+}$observed at $\mathrm{m} / z 311$ was probably generated from a pseudo-molecular ion by loss of ethanol.

Attempts to assign the relative configuration of 1 were made recording a NOESY spectrum. The measured NOESY correlations are reported in Table 2, but since there is no clear correlation between the protons of the methoxy and ethoxy groups, these data alone were not sufficient to assign the relative configuration of the two chiral centres (C-7 and C-15). To better interpret
Table 2. NOESY data for olicleistanone (1).

\begin{tabular}{lccc}
\hline Irradiated & Observed & Irradiated & Observed \\
\hline $\mathrm{H}-11$ & $\mathrm{H}_{2}-1$ & $\mathrm{OMe}$ & $\mathrm{H}_{3}-17$ \\
$\mathrm{H}_{2}-20$ & $\mathrm{H}_{3}-21$ & $\mathrm{H}_{3}-18$ & $\mathrm{H}_{2}-20$ \\
$\mathrm{H}-15$ & $\mathrm{H}_{3}-17, \mathrm{OMe}$ & & \\
\hline
\end{tabular}

Table 3. Experimental and calculated ${ }^{3} J_{\mathrm{HH}}$ values $(\mathrm{Hz})$ for olicleistanone (1) a.

\begin{tabular}{rccccc}
\hline \multirow{2}{*}{ Experimental } & \multicolumn{3}{c}{$\begin{array}{c}\text { Calculated Calculated } \\
\text { (Karplus) }\end{array}$} & $\begin{array}{c}\text { Calculated Calculated } \\
\text { (DFT) }\end{array}$ & $\begin{array}{c}\text { (Karplus) } \\
(\mathrm{DFT})\end{array}$ \\
\cline { 3 - 6 } & & \multicolumn{2}{c}{$(7 S, 15 S)-1$} & \multicolumn{2}{c}{$(7 S, 15 R)-1$} \\
\hline H-15/H-16a & 3.3 & 3.14 & 4.05 & 7.24 & 9.26 \\
H-15/H-16b & n.d. & 0.89 & 0.70 & 7.81 & 8.63 \\
\hline
\end{tabular}

a values calculated either by a Karplus curve or by DFT at B3LYP/ pcJ-0 level in vacuo, as Boltzmann average of all structures obtained by DFT geometry optimization (see text).

n.d.: Not detected.

NMR data, a molecular modelling study was undertaken. First, two diastereomeric structures $(7 S, 15 S)-\mathbf{1}$ and $(7 S, 15 R)-\mathbf{1}$ were generated and their possible conformations were explored by means of a conformational search with molecular mechanics (Merck molecular force field, MMFF). Geometry optimizations were then run with the density functional method (DFT) at the B97M-V/6$311+\mathrm{G}(2 \mathrm{df}, 2 \mathrm{p}) / / \mathrm{B} 3 \mathrm{LYP} / 6-31 \mathrm{G}(\mathrm{d})$ level, using the computational protocol for the prediction of ${ }^{13} \mathrm{C}$ chemical shifts of flexible compounds, developed by Hehre et al. (2019). For the two diastereomers, six or ten conformers were found with detectable populations at room temperature. The various conformers differed in the conformation of the methoxy and ethoxy groups, but also in the puckering of ring A. A clear difference between the two diastereomers was the orientation of $\mathrm{H}-15$, which was predominantly pseudo-equatorial in $(7 S, 15 S)$-1 and pseudoaxial $(7 S, 15 R)-1$. Thus, we presumed that the coupling constants between $\mathrm{H}-15$ and $\mathrm{H}-16 \mathrm{a} / \mathrm{H}-16 \mathrm{~b}$ could be used to discriminate between the two isomers. Experimentally, $\mathrm{H}-15$ appears as a doublet with splitting of $3.3 \mathrm{~Hz}$, meaning that one $J_{15 / 16}$ was small $(3.3 \mathrm{~Hz})$ and the other was negligible. This agreed with a pseudo-equatorial orientation. ${ }^{3} J_{15 / 16}$ were then estimated with Karplus curve and spin-spin coupling calculations at B3LYP/pcJ-0 level. These results are shown in Table 3, and strongly support the assignment of $\mathbf{1}$ as $\left(7 S^{*}, 15 S^{*}\right)-\mathbf{1}$. ${ }^{13} \mathrm{C}$-NMR calculations were then run at the B3LYP/6-31G(d) level. The estimated root-mean-square (rms) error between experimental and calculated ${ }^{13} \mathrm{C}$ chemical shifts was acceptable (2.4-2.5) 
but similar for both isomers, confirming the $\left(7 S^{*}, 15 S^{*}\right)$-1 assignment but without further supporting it. Nevertheless, we consider that the argument based on J-couplings is accurate enough to assign the relative configuration.

For the absolute configuration, the ECD spectrum of a solution of 1 in acetonitrile $(1 \mathrm{mM}, 0.01 \mathrm{~cm}$ cell) was measured. The ECD spectrum was not distinguishable from the baseline over the whole range $(185-400 \mathrm{~nm}$, data not shown), despite the optimal absorption ( 0.3 to 0.8 for the absorption peaks). It therefore must be concluded that the isolated sample of $\mathbf{1}$ was a racemate. Racemic natural products are rare, and are thought to result from nonenzymatic reactions (Zask and Ellestad, 2018). The chirality centre at C-7 of $\mathbf{1}$ is a tertiary benzylic carbon in a position to carbonyl group and it is therefore easily subject to racemization. However, racemization of this centre does not occur in a post-synthetic step, otherwise two diastereomers would be obtained. On the other hand, the isolated $(7 S, 15 S)-\mathbf{1}$ isomer was more stable than its $(7 S, 15 R)$ diastereomer by about $2 \mathrm{kcal} \mathrm{mol}^{-1}$ at the present level of calculation, suggesting that if the chiral centre at C-15 was biosynthesized in a later step than C-7, its configuration would be dictated by that at C-7.

All metabolites ( 1 to $\mathbf{6}$ ) isolated in this study were screened for phytotoxic, antifungal, antioomycete and zootoxic activities.

Except for compound 2, phytotoxicity was not detected for any of the metabolites (at $1 \mathrm{mg} \mathrm{mL}^{-1}$ ) when applied to leaves of Phaseolus vulgaris, Quercus suber, or Juglans regia. Sphaeropsidin A (2) caused necrotic lesions on leaves of all the plant species tested, with mean lesion sizes of $75.6 \mathrm{~mm}^{2}$ on P. vulgaris, $163.3 \mathrm{~mm}^{2}$ on J. regia and $15.1 \mathrm{~mm}^{2}$ on Q. suber.

In the assays of antifungal activity, sphaeropsidin A (2) inhibited mycelium growth of all the plant pathogens tested (100\% inhibition rate). Diplopimarane (4) completely inhibited growth of Athelia rolfsii and partially inhibited growth of $D$. corticola, $P$. cambivora and $P$. lacustris, inhibition from $56 \%$ to $75 \%$. No colony growth inhibition was observed for the other four metabolites at the concentration used.

In the brine shrimp larvae bioassay, which is widely used for toxicology and ecotoxicology studies, compounds 1, 4 and 6 (at $100 \mu \mathrm{g} \mathrm{mL}^{-1}$ ) caused $100 \%$ larval mortality. Compound 2 caused 51\% larval mortality, and compounds $\mathbf{3}$ and $\mathbf{5}$ were inactive.

Cleistanthane-type diterpenoids are produced by different fungi and plants, but few examples of cleistanthane nor-diterpenoids are reported. Among them there are aspergiloids A, B, F and G isolated from the fermentation broth extract of Aspergillus sp. YXf3, an endophytic fungus from Ginkgo biloba. However, no biologi- cal activities have been reported for these compounds (Guo et al., 2012; Yan et al., 2013).

Sphaeropsidin A, C and G, as well as B, D, E and F, previously isolated from $D$. cupressi, D. mutila (Sparapano et al., 2004), and D. corticola (Masi et al., 2018), belong to the group of tricyclic and tetracyclic unarranged pimarane diterpenoids, which are well-known fungus and plant metabolites (Reveglia et al., 2018). Smardesines and chenopodolins also belong to this group of compounds. These cytotoxic and phytotoxic metabolites were isolated from Smardaea sp. AZ0432 living in the moss Ceratodon purpureus (Wang et al., 2011), and from Phoma chenopodiicola, a fungus proposed for biocontrol of the weed plant Chenopodoium album (Cimmino et al., 2013; Evidente et al., 2015). Sphaeropsidin A and its 6-O-acetyl derivative also showed antimicrobial (Evidente et al., 2011) and anticancer activity (Lallemand et al., 2012; Ingels et al., 2017; Masi et al., 2018).

Melleins are 3,4-dihydroisocoumarins, which are produced by many fungi of various genera as well as plants, insects and bacteria. These compounds have several phytotoxic, zootoxic and antifungal effects (Reveglia et al., 2020). (-)-Mellein was toxic on grapevine leaves and grapevine calli (Djoukeng et al., 2009; Ramirez-Suero et al., 2014, Masi et al., 2018), and was detected in symptomatic and asymptomatic grapevine wood samples and green shoots (Djoukeng et al., 2009) from plants with Botryosphaeria dieback and leaf stripe. The role of this compound in pathogenesis was investigated by examining the extent to which it caused expression of defenserelated genes in grapevine calli (Ramirez-Suero et al., 2014). Recently, (-)-mellein was also identified as a metabolite of Lasiodiplodia euphorbiaceicola during screening of phytotoxic metabolites isolated from Lasiodiplodia spp. infecting grapevine in Brazil (Cimmino et al., 2017b), and from Sardiniella urbana, a pathogen from declining European hackberry trees in Italy (Cimmino et al., 2019).

It is well known that fungal phytotoxins are closely related to host plant interactions. These compounds play key roles inducing virulence and pathogenicity of fungi. The host/pathogen interaction is the first process of the complex mechanism of infection. Fungal pathogens produce enzymes to degrade host wood cell walls, and the fungal toxins penetrate vessels and metabolize dead host tissues. The toxins then translocate to branches and leaves distant from the infection points, inducing chlorosis and necrosis (Durbin et al., 1989; Ballio, 1991; Möbius and Hertweck 2009; Keller, 2019). Thus, the phytotoxicity of $D$. olivarum was probably due to production of sphaeropsidin A (2), as outlined in the present study.

Phytotoxins have also been shown to possess herbicidal, antimicrobial and insecticidal activities (Spara- 
pano et al. 2004; Evidente et al. 2011; Cimmino et al. 2015; Barilli et al., 2017; Aznar et al. 2019). Drug-based phytotoxins can also be used in medicine against some important human diseases, such as cancer, malaria, dengue and yellow fevers, and against fungal and bacterial infections (Bajsa et al., 2007; Evidente et al., 2014, Masi et al. 2017; Masi et al., 2018; Roscetto et al., 2020). Some of these toxins could also be produced in industrial large scale, and be formulated for applications in agriculture and medicine. Among the toxins previously isolated, and also from D. olivarum, sphaeropsidin A (2) is a phytotoxin with strong potential for drug development (Ingles et al., 2017; Masi et al., 2018; Roscetto et al., 2020).

In conclusion, this study was the first to investigate secondary metabolites produced by $D$. olivarum, an emerging pathogen of forest trees in the Mediterranean region. The results confirm that Botryosphaeriaceae are sources of bioactive secondary metabolites, some of which have potential for applications in biotechnology sectors.

Among the metabolites produced in vitro by D. olivarum, sphaeropsidin $\mathrm{A}$ and diplopimarane inhibited vegetative growth of four plant pathogens belonging to different phyla. Additionally, the strong activity of the newly identified metabolite, olicleistanone (1), against A. salina deserves detailed investigation, because several applications of A. salina in toxicology and ecotoxicology continue to be widely used.

\section{ACKNOWLEDGEMENTS}

This study was partially supported by the "Fondo di Ateneo per la ricerca 2019", internal funding provided by the University of Sassari. Antonio Evidente is associated with the Istituto di Chimica Biomolecolare del CNR, Pozzuoli, Italy.

\section{SUPPORTING INFORMATION}

$1 \mathrm{D}$ and 2D NMR data for 1 and HRESI-MS spectra of 1-3.

\section{LITERATURE CITED}

Abou-Mansour E., Débieux J.L., Ramírez-Suero M., Bénard-Gellon M., Magnin-Robert M., ... Serrano M., 2015. Phytotoxic metabolites from Neofusicoccum parvum, a pathogen of Botryosphaeria dieback of grapevine. Phytochemistry 115: 207-215.
Adamson K., Klavina D., Drenkhan R., Gaitnieks T., Hanso M., 2015. Diplodia sapinea is colonizing the native Scots pine (Pinus sylvestris) in the northern Baltics. The European Journal of Plant Pathology 143: 343-350.

Alves A., Linaldeddu B.T., Deidda A., Franceschini A., 2014. The complex of Diplodia specie associated with Fraxinus and some other woody hosts in Italy and Portugal. Fungal Diversity 67: 143-156.

Andolfi A., Maddau L., Basso S., Linaldeddu B.T., Cimmino A., ... Evidente A., 2014. Diplopimarane, a 20-nor-ent-pimarane produced by the oak pathogen Diplodia quercivora. Journal of Natural Products 77: 2352-236.

Aznar-Fernández T., Cimmino A., Masi M., Rubiales D., Evidente A. 2019. Antifeedant activity of long-chain alcohols, and fungal and plant metabolites against pea aphid (Acyrthosiphon pisum) as potential biocontrol strategy. Natural Product Research, 33: 2471-2479.

Bajsa J., Singh K., Nanayakkara D., Duke S.O., Rimando A.M., Evidente A., Tekwani B.L. 2007. A survey of synthetic and natural phytotoxic compounds and phytoalexins as potential antimalarial compounds. Biological and Pharmaceutical Bulletin, 30: 1740-1744.

Ballio, A. 1991. Non-host-selective fungal phytotoxins: biochemical aspects of their mode of action. Experientia 47: 783-790.

Barilli E., Cimmino A., Masi M., Evidente M., Rubiales D., Evidente A. 2017. Inhibition of early development stages of rust fungi by the two fungal metabolites cyclopaldic acid and epi-epoformin. Pest Management Science 73: 1161-1168.

Berger S., Braun S., 2004. 200 and More Basic NMR Experiments: A Practical Course. 1st ed. Wiley-VCH, Weinheim, Germany, $418 \mathrm{pp}$.

Breitmaier E., Voelter W., 1987. Carbon-13 NMR Spectroscopy. VCH, Weinheim, Germany, 183-280.

Capon, R., 2020. Extracting value: mechanistic insights into the formation of natural product artifacts-case studies in marine natural products. Natural Product Reports 37: 55-79

Cimmino A., Andolfi A., Zonno M.C., Avolio F., Santini A., ... Evidente A., 2013. Chenopodolin: a phytotoxic unrearranged ent-pimaradiene diterpene produced by Phoma chenopodicola, a fungal pathogen for Chenopodium album biocontrol. Journal of Natural Products 76, 1291-1297.

Cimmino A., Masi M., Evidente M., Superchi S., Evidente, A. 2015. Fungal phytotoxins with potential herbicidal activity: chemical and biological characterization. Natural Product Reports 32: 1629-1653. 
Cimmino A., Maddau L., Masi M., Evidente M., Linaldeddu B.T., Evidente A., 2016. Further secondary metabolites produced by Diplodia corticola, a fungal pathogen involved in cork oak decline. Tetrahedron 72: 6788-6793.

Cimmino A., Maddau L., Masi M., Linaldeddu B.T., Pescitelli G., Evidente A., 2017a. Fraxitoxin, a new isochromanone isolated from Diplodia fraxini. Chemistry \&. Biodiversity 14: e1700325.

Cimmino A., Cinelli T., Masi M., Reveglia P., da Silva M.A., ... Evidente A., 2017b. Phytotoxic lipophilic metabolites produced by grapevine strains of Lasiodiplodia species in Brazil. Journal of Agricultural and Food Chemistry 65: 1102-1107.

Cimmino A., Maddau L., Masi M., Linaldeddu B.T., Evidente A., 2019. Secondary metabolites produced by Sardiniella urbana, a new emerging pathogen on European hackberry. Natural Product Research 33: 1862-1869.

Devappa R.K., Makkar H.P., Becker K., 2011. Jatropha diterpenes: a review. Journal of the American Oil Chemists' Society 88: 301-322.

Djoukeng J.D., Polli S., Larignon P., Abou-Mansour E., 2009. Identification of phytotoxins from Botryosphaeria obtusa, a pathogen of 525 black dead arm disease of grapevine. European Journal of Plant Pathology 124: 303-308.

Durbin R.D., Ballio A., Graniti A., 1989. Phytotoxins and Plant Pathogenesis. Nato ASI Subseries H, Vol. 27, Springer-Verlag, Heidelberg, Germany, 508 pp.

Evidente A., Sparapano L., Motta A., Giordano F., Fierro O., Frisullo S., 1996. A phytotoxic pimarane diterpene of Sphaeropsis sapinea f. sp. cupressi, the pathogen of a canker disease of cypress. Phytochemistry 42: 1541-1546.

Evidente A., Sparapano L., Fierro O., Bruno G., Giordano F., Motta A., 1997. Sphaeropsidins B and C, phytotoxic pimarane diterpenes from Sphaeropsis sapinea f. sp. cupressi and Diplodia mutila. Phytochemistry 45: 705-713.

Evidente A., Punzo B., Andolfi A., Cimmino A., Melck D., Luque J., 2010. Lipophilic phytotoxins produced by Neofusicoccum parvum, a grapevine canker agent. Phytopathologia Mediterranea 49: 74-79.

Evidente A., Venturi V., Masi M., Degrassi G., Cimmino A., ... Andolfi A., 2011. In vitro antibacterial activity of sphaeropsidins and chemical derivatives toward Xanthomonas oryzae pv. oryzae, the causal agent of rice bacterial blight. Journal of Natural Products 74: 2520-2525.

Evidente A., Masi M., Linaldeddu B.T., Franceschini A., Scanu B., ... Maddau, L. 2012. Afritoxinones A and
B, dihydrofuropyran-2-ones produced by Diplodia africana the causal agent of branch dieback on Juniperus phoenicea. Phytochemistry 77: 245-250.

Evidente A., Kornienko A., Cimmino A., Andolfi A., Lefranc F., ... Kiss R. 2014. Fungal metabolites with anticancer activity. Natural Product Reports 31: 617627.

Evidente M., Cimmino A., Zonno M.C., Masi M., Berestetskyi A., ... Evidente A., 2015. Phytotoxins produced by Phoma chenopodiicola, a fungal pathogen of Chenopodium album. Phytochemistry 117: 482-488.

Granata G., Faedda R., Sidoti A., 2011. First report of canker caused by Diplodia olivarum on carob tree in Italy. Plant Disease 100: 2483-2491.

Guo Z.K., Yan T., Guo Y., Song Y.C., Jiao R.H., ... Ge H.M., 2012. p-Terphenyl and diterpenoid metabolites from endophytic Aspergillus sp. YXf3. Journal of Natural Products 75: 15-21.

Hehre W., Klunzinger P., Deppmeier B., Driessen A., Uchida N., ... Takata Y., 2019. Efficient protocol for accurately calculating ${ }^{13} \mathrm{C}$ chemical shifts of conformationally flexible natural products: scope, assessment, and limitations. Journal of Natural Products 82: 2299-2306.

Ingels A., Dinhof C., Garg A.D., Maddau L., Masi M., ... Mathieu V., 2017. Computed determination of the in vitro optimal chemocombinations of sphaeropsidin A with chemotherapeutic agents to combat melanomas. Cancer Chemotherapy and Pharmacology 79: 971-983.

Lallemand B., Masi M., Maddau L., De Lorenzi M., Dam R., ... Evidente A., 2012. Evaluation of in vitro anticancer activity of sphaeropsidins A-C, fungal rearranged pimarane diterpenes, and semisynthetic derivatives. Phytochemistry Letters 5: 770-775.

Lazzizera C., Frisullo S., Alves A., Lopes J., Phillips A.J.L., 2008. Phylogeny and morphology of Diplodia species on olives in southern Italy and description of Diplodia olivarum sp. nov. Fungal Diversity 31: 63-71.

Lim S.H., Low Y.Y., Subramaniam G., Abdullah Z.; Thomas N.F., Kam T.S., 2013. Lumusidines A-D and villalstonidine $\mathrm{F}$, macroline-macroline and macroline-pleiocarpamine bisindole alkaloids from Alstonia macrophylla. Phytochemistry 87: 148-156.

Linaldeddu B.T., Maddau L., Franceschini A., Alves A., Phillips A.J.L., 2016. Botryosphaeriaceae species associated with lentisk dieback in Italy and description of Diplodia insularis sp. nov. Mycosphere 7: 962-977.

Lopes A., Linaldeddu B.T., Phillips A.J.L., Alves A., 2018. Mating type gene analyses in the genus Diplodia: from cryptic sex to cryptic species. Fungal Biology 122: 629-638. 
Keller N.P. 2019. Fungal secondary metabolism: Regulation, function and drug discovery. Nature Review Microbiology 17: 167-180.

Maltese F., van der Kooy F., Verpoorte R. 2009. Solvent derived artifacts in natural products chemistry. Natural Product Communication 4: 447-454.

Manca D., Bregant C., Maddau L., Pinna C., Montecchio L., Linaldeddu B.T., 2020. First report of canker and dieback caused by Neofusicoccum parvum and Diplodia olivarum on oleaster in Italy. Italian Journal of Mycology 49: 85-91.

Martin D.K.H., Turcotte R.M., Miller T.M., Munck I.A., Aćimović S.G., ... Kasson M.T., 2017. First report of Diplodia corticola causing stem cankers and associated vascular occlusion of northern red oak (Quercus rubra) in West Virginia. Plant Disease 101: 380.

Masi M., Maddau L., Linaldeddu B.T.; Cimmino A., D’Amico W., ... Evidente A., 2016. Bioactive secondary metabolites produced by the oak pathogen Diplodia corticola. Journal of Agricultural and Food Chemistry 64: 217-225.

Masi M., Cimmino A., Tabanca N., Becnel J.J., Bloomquist J.R., Evidente A. 2017. A survey of bacterial, fungal and plant metabolites against Aedes aegypti (Diptera: Culicidae), the vector of yellow and dengue fevers and Zika virus. Open Chemistry 15: 156-166.

Masi M., Maddau L., Linaldeddu B.T., Scanu B., Evidente A., Cimmino A., 2018. Bioactive metabolites from pathogenic and endophytic fungi of forest trees. Current Medicinal Chemistry 25: 208-252.

Masi M., Aloi F., Nocera P., Cacciola S.O., Surico G., Evidente A., 2020. Phytotoxic metabolites isolated from Neufusicoccum batangarum, the causal agent of the scabby canker of cactus pear (Opuntia ficus-indica L.). Toxins 12: 126.

Mobius N., Hertweck C. 2009. Fungal phytotoxins as mediators of virulence. Current Opinion in Plant Biology 12: 390-398.

Nakanishi K., Solomon P.H., 1977. Infrared Absorption Spectroscopy. 2nd ed. Holden Day, Oakland, California, USA, 17-44.

Pérez C., Wingfield M., Slippers B., Altier N., Blanchette R., 2010. Endophytic and canker-associated Botryosphaeriaceae occurring on non-native Eucalyptus and native Myrtaceae trees in Uruguay. Fungal Diversity 41: 53-69.

Pinkerton F., Strobel G., 1976. Serinol as an activator of toxin production in attenuated cultures of $\mathrm{Hel}$ minthosporium sacchari. PNAS 73: 4007-4011.

Pretsch E., Bühlmann P., Affolter C., 2000. Structure Determination of Organic Compounds - Tables of
Spectral Data. 3rd ed. Springer-Verlag: Berlin, Germany, 161-243.

Ramírez-Suero M., Bénard-Gellon M., Chong J., Lalou, H., Stempien E., ... Bertsch, C., 2014. Extracellular compounds produced by fungi associated with Botryosphaeria dieback induce differential defence gene expression patterns and necrosis in Vitis vinifera $\mathrm{cv}$. Chardonnay cells. Protoplasma 251: 1417-1426.

Reveglia P., Cimmino A., Masi M., Nocera P., Berova N., ... Evidente, A., 2018. Pimarane diterpenes: Natural source, stereochemical configuration, and biological activity. Chirality 30: 1115-1134.

Reveglia P., Masi M., Evidente A., 2020. Melleins, intriguing natural compounds. Biomolecules 10: 772.

Roscetto E., Masi M., Esposito M., Di Lecce R., Delicato A., Maddau L., ... Catania M.R. 2020. Anti-biofilm activity of the fungal phytotoxin sphaeropsidin A against clinical isolates of antibiotic-resistant bacteria. Toxins, 12: 444.

Shen C.P., Luo J.G., Yang M.H., Kong L.Y. 2015. A pair of novel 2,3-seco cafestol-type diterpenoid epimers from the twigs of Tricalysia fruticosa. Tetrahedron Letters 56: 1328-1331.

Sparapano L., Bruno G., Fierro O., Evidente A., 2004. Studies on structure-activity relationship of sphaeropsidins A-F, phytotoxins produced by Sphaeropsis sapinea f. sp. cupressi. Phytochemistry 65: 189-198.

Wang H.; Wu F.H.; Xiong F.; Wu J. J.; Zhang L.Y.; ... Zhao, S.X., 2006. Iridoids from Neopicrorhiza scrophulariiflora and their hepatoprotective activities in vitro. Chemical and Pharmaceutical Bulletin 54: 1144-1149.

Wang X.N., Bashyal B.P., Wijeratne E.K., U’Ren J.M., Liu M.X., ... Gunatilaka, A.L., 2011. Smardaesidins A-G, isopimarane and 20-nor-isopimarane diterpenoids from Smardaea sp., a fungal endophyte of the moss Ceratodon purpureus. Journal of Natural Products 74: 2052-2061.

Xiong L., Zhou Q.M., Zou Y., Chen M.H., Guo L., ... Peng C., 2015. Leonuketal, a spiroketal diterpenoid from Leonurus japonicus. Organic Letters 17: 62386241.

Yan, T., Guo, Z.K., Jiang, R., Wei, W., Wang, T., ... Ge, H.M., 2013. New flavonol and diterpenoids from the endophytic fungus Aspergillus sp. YXf3. Planta Medica 79: 348-352.

Zask A., Ellestad G., 2018. Biomimetic syntheses of racemic natural products. Chirality 30: 157-164.

Zhang P., Tang C., Yao S., Ke C., Lin G., ... Ye, Y., 2016. Cassane diterpenoids from the pericarps of Caesalpinia bonduc. Journal of Natural Products 79: 24-29. 